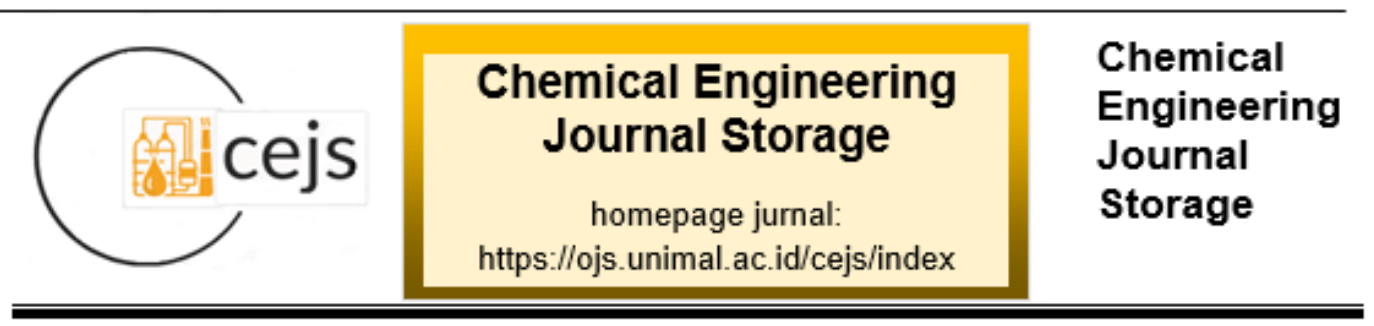

\title{
PENGARUH SUHU DAN WAKTU REAKSI TRANSESTERIFIKASI MINYAK JARAK KEPYAR (Castor Oil) TERHADAP METIL ESTER DENGAN MENGGUNAKAN KATALIS ABU TANDAN KOSONG KELAPA SAWIT
}

\author{
Lidya Permata Lestari $^{1}$, Meriatna ${ }^{1}$, Suryati ${ }^{1}$, Jalaluddin ${ }^{1}$, Novi Sylvia ${ }^{1}$ \\ ${ }^{1}$ Jurusan Teknik Kimia, Fakultas Teknik, Universitas Malikussaleh \\ Kampus Utama Cot Teungku Nie Reuleut, Muara Batu, Aceh Utara - 24355 \\ Korespondensi:HP: 08126563565, e-mail: meriatna@unimal.ac.id
}

\begin{abstract}
Abstrak
Biodiesel merupakan bahan bakar alternatif untuk mesin diesel yang terdiri dari alkil monoester dari minyak tumbuhan atau lemak hewan. Minyak jarak kepyar (Castor Oil) adalah minyak nabati yang diperoleh dari ekstrak biji tanaman jarak kepyar. Tujuan dari penelitian ini adalah untuk memanfaatkan minyak jarak kepyar dalam pembuatan biodiesel dengan menggunakan katalis heterogen yang berasal dari tandan kosong kelapa sawit yang dikalsinasi pada suhu $600{ }^{\circ} \mathrm{C}$ selama 6 jam. Proses transesterifiksi mereaksikan minyak dan metanol untuk menghasilkan metil ester dan gliserol. Metil ester yang dihasilkan pada lapisan atas dipisahkan dari gliserol dan kemudian dimurnikan. Pengaruh dari berbagai variabel proses seperti pengaruh suhu dan waktu reaksi diamati dalam percobaan ini. Sifat-sifat biodiesel seperti Yield paling tinggi diperoleh pada suhu $65{ }^{\circ} \mathrm{C}$ selama 100 menit dengan katalis $3(\mathrm{~m} / \mathrm{m}) \%$. yaitu sebesar $76,62 \%$, kemudian untuk densitas diperoleh hasil terbaik 0,863 mg/l pada suhu $55{ }^{\circ} \mathrm{C}$ selama 80 menit dengan katalis $3(\mathrm{~m} / \mathrm{m}) \%$, selanjutnya untuk viskositas diperoleh $5,25 \mathrm{~mm}^{2} / \mathrm{s}$ pada suhu $65{ }^{\circ} \mathrm{C}$ selama 100 menit dengan katalis 3 $(\mathrm{m} / \mathrm{m}) \%$, kemudian kadar air diperoleh $0,038 \%$ vol pada suhu $60{ }^{\circ} \mathrm{C}$ dan selama 80 menit dengan katalis $3(\mathrm{~m} / \mathrm{m}) \%$. dan bilangan asam diperoleh $0,48 \mathrm{Mg}$ $\mathrm{KOH} / \mathrm{g}$ pada suhu $50^{\circ} \mathrm{C}$ selama 100 menit dengan katalis $3(\mathrm{~m} / \mathrm{m}) \%$. Hasil yang diperoleh pada penelitian ini menunjukkan bahwa katalis yang berbasis tandan kosong kelapa sawit dapat digunakan untuk memproduksi biodiesel.

Kata kunci: Biodiesel, katalis, suhu, waktu, transesterfikasi, minyak jarak kepyar
\end{abstract}

\section{Pendahuluan}

Indonesia merupakan negara dengan jumlah penduduk terbesar keempat di dunia. Jumlah penduduk ini akan mempengaruhi peningkatan konsumsi energi. Penggunaan kendaraan bermotor semakin mengalami peningkatan dari tahun ke 
tahun. Sektor industri juga semakin berkembang pesat. Dari hal ini terlihat jelas bahwa konsumsi energi di Indonesia juga semakin tinggi. Sementara itu cadangan minyak bumi dunia semakin menipis dan penggunaan minyak bumi berkualitas rendah (kandungan sulfur tinggi) dapat menyebabkan polusi udara yang tidak baik bagi kesehatan (Erlinda Ningsih, 2017).

Produksi biodiesel yang dikembangkan saat ini umumnya dibuat dari minyak tumbuhan (minyak kedelai, minyak sawit mentah, minyak lobak), lemak hewani (lemak ayam, lemak babi), dan bahkan dari minyak goreng bekas. Untuk memproduksi biodiesel, proses reaksi yang digunakan diantaranya adalah transesterifikasi berkatalis basa $(\mathrm{NaOH}, \mathrm{KOH})$, esterifikasi berkatalis asam $(\mathrm{HCI})$, dan metode supercritical. Proses biodiesel dengan metode transesterifikasi berkatalis basa, baik natrium hidroksida maupun natrium metoksida, banyak digunakan secara komersial namun metode ini memiliki laju reaksi yang lambat dan ada kalanya reaksi berhenti sebelum terkonversi sempurna menjadi produk biodiesel (Karim Abdullah, 2016).

Pada umumnya pembuatan biodiesel dengan menggunakan minyak nabati adalah dengan mereaksikan asam lemak bebas dengan alkohol. Alkohol bertindak sebagai pelarut proses ekstraksi dan sebagai reagent pada reaksi transesterifikasi selama ekstraksi reaksi berlangsung. Alkohol yang paling sering digunakan adalah metanol. Metanol bukan pelarut yang baik untuk minyak, namun kebanyakan peneliti menggunakan metanol sebagai media pengekstrak. Pemilihan ini lebih didasarkan pada harganya yang lebih murah dan rantai paling pendek, sehingga paling reaktif untuk reaksi esterifikasi dan transesterifikasi. Penggunaan etanol pada pembuatan biodiesel ini dapat menghasilkan konversi biodiesel yang cukup tinggi yaitu 99.8\%, akan tetapi etanol dengan kemurnian 98\%. membutuhkan biaya produksi yang tinggi pula. Untuk mengurangi biaya produksi yang tinggi maka digunakan digunakan etanol teknis (Saripah sobah, Muhammad Naufal Ariq H, 2021).

Salah satu bahan alami yang dapat digunakan sebagai material dalam pembuatan biodiesel adalah tanaman jarak, tanaman jarak telah dikenal sejak 
masa penjajahan. Penyebaran tanaman jarak di Indonesia, terdapat di daerah yang memiliki curah hujan yang hanya $700-1200 \mathrm{~mm}$ per tahun. Daerah yang memiliki curah hujan tersebut dinilai sangat sesuai untuk pengembangan tanaman jarak meliputi bagian pantai timur Aceh, Jawa Barat, Jawa Timur, Madura, Bali, Nusa Tenggara Barat, Flores, Sulawesi Utara dan Sulawesi Tenggara (Sinaga, Haryanto, \& Triyono, 2014).

Minyak jarak kepyar (Castor oil) merupakan minyak nabati yang prospektif untuk dikembangkan sebagai bahan baku biodiesel karena minyak jarak kepyar merupakan bahan baku non pangan sehingga berpotensi menggantikan minyak kelapa sawit untuk beragam aplikasi non pangan termasuk sebagai bahan baku biodiesel. Namun minyak nabati tersebut memiliki beberapa kelemahan antara lain nilai kalor yang rendah, densitas, dan viskositasnya masih tinggi. Karena viskositas yang tinggi akan menyumbat saluran bahan bakar, mengurangi atomisasi bahan bakar dan meningkatkan penetrasi semprotan bahan bakar yang mengakibatkan deposit mesin yang tinggi serta penebalan minyak pelumas (Tazora, 2011).

Transesterifikasi merupakan reaksi organik dimana suatu senyawa ester diubah menjadi senyawa ester lain melalui pertukaran gugus alkohol dari ester dengan gugus alkil dari senyawa alkohol lain. Sedikit berbeda dengan reaksi hidrolisis, pada reaksi transesterifikasi pereaksi yang digunakan bukan air melainkan alkohol. Metanol lebih umum digunakan untuk proses transesterifikasi karena harganya yang lebih murah dibandingkan alkohol lain. Namun penggunaan alkohol lain seperti etanol dapat menghasilkan hasil yang serupa. Faktor penting yang dapat mempengaruhi reaksi esterifikasi dan transesterifikasi adalah penggunaan metanol yang berlebih agar air yang terbentuk dari reaksi dapat diserap oleh metanol sehingga tidak menghalangi jalannya reaksi pengubahan asam lemak bebas menjadi metil ester. Dimungkinkan terjadi kompetisi dari metanol dalam reaksi esterifikasi sebagai reaktan. Peningkatan jumlah alkohol secara berlebih dapat meminimalkan jumlah katalisyang dibutuhkan, namun kekurangan yang ditimbulkan dari alkohol yang berlebihan ini adalah saat 
pemisahan ester dan gliserol, terutama untuk molekul alkohol yang lebih besar.

Proses pemisahan dilakukan dengan penambahan air, dimana air akan menarik gliserol dari fasa ester. Fasa yang berada di lapisan bawah merupakan campuran sabun,gliserol, dan air. Hasil yang tampak dari reaksi transesterifikasi terbentuk tiga lapisan,yaitu metil ester (biodiesel) pada lapisan atas, gliserol pada lapisan tengah, dan sabun pada lapisan bawah. Pemisahan metil ester dari produk samping lainnya dilakukan dalam corong pemisah, untuk mendapatkan biodiesel murni. Penggunaan katalis basa/alkali harus seminimal mungkin, karena jumlah sabun (reaksi saponifikasi) akan meningkat dengan semakin bertambahnya jumlah katalis yang ditambahkan. Saponifikasi/penyabunan (hidrolisa basa) adalah reaksi reaksi hidrolisis suatu ester yang terjadi bolak- bali/dua arah (reaksi irreversible) (Alif Aldino Rizkita, Anisa Helena.I.P, Anita Puspitasari Fina Rifqiyani, M. Faishal, 2016).

\section{Bahan dan Metode}

Bahan dan peralatan yang diperlukan dalam penelitian ini antara lain adalah minyak jarak kepyar (Castor Oil, metanol 96\%, kertas saring, $\mathrm{NaOH} \mathrm{0,1} \mathrm{N,} \mathrm{KOH}$ 0,1 N, Abu Tandan Kosong Kelapa Sawit 3\%, Indikator PP 1\%, labu leher tiga $500 \mathrm{ml}$, ayakan mesh 100, termometer, neraca analitik, corong pemisah, erlenmeyer, hot plate, seperangkat distilasi, cawan porselin, buret, Stopwatch, piknometer ostwald, viscometer, magnetic stirrer.

Proses pembuatan biodiesel terdiri dari tiga tahapan yaitu preparasi abu tandan kosong kelapa sawit, reaksi transesterifikasi, proses pemurnian. Variabel tetap pada penelitian ini yaitu massa minyak jarak kepyar (Castor Oil), Perbandingan mol minyak terhadap methanol 1:6, Katalis Abu Tandan Kosong Kelapa Sawit 3\% dari berat minyak. Variabel bebas pada penelitian ini yaitu variasi suhu reaksi $50{ }^{\circ} \mathrm{C}, 55^{\circ} \mathrm{C}, 60{ }^{\circ} \mathrm{C}, 65{ }^{\circ} \mathrm{C}$ dan waktu reaksi 60 menit, 80 menit, 100 menit dan variabel terikat yaitu Kadar FFA, densitas biodiesel pada suhu $40{ }^{\circ} \mathrm{C}$, viskositas biodiesel $40{ }^{\circ} \mathrm{C}$, kadar air, yield, bilangan asam, analisa 
komposisi senyawa Biodiesel (GC-MS), Uji Scanning Electron Microscopy (SEM).

Pada proses preparasi, tandan kosong kelapa sawit dimasukkan ke dalam furnace dengan suhu $600{ }^{\circ} \mathrm{C}$ selama 6 jam. Kemudian abu yang dihasilkan di ayak dengan menggunakan mesh 100. Selanjutnya abu tandan kosong kelapa sawit dimasukkan ke dalam oven dengan suhu $110^{\circ} \mathrm{C}$, proses ini disebut dengan proses reashing. Reashing adalah adalah suatu proses abu tandan kosong kelapa sawit di abukan kembali hingga mencapai temperatur yang telah di tentukan yang bertujuan untuk menghilangkan sisa-sisa karbon.

Proses transesterifikasi dilakukan pada sebuah labu leher tiga dengan mencampurkan minyak jarak kepyar (Castor Oil) dan metanol dengan perbandingan minyak jarak kepyar (Castor Oil) terhadap metanol 1:6 dengan menggunakan katalis abu tandan kosong kelapa sawit 3\% dari berat minyak dan ditambahkan metanol dari perbandingan minyak jarak kepyar terhadap metanol. Pertama minyak dipanaskan hingga mencapai suhu $60{ }^{\circ} \mathrm{C}$. bersamaan diaduk menggunakan magnetic stirrer. Kemudian ditambahkan metanol dan katalis abu tandan kosong kelapa sawit dan dilakukan pengadukan hingga homogen dengan variasi suhu reaksi $50{ }^{\circ} \mathrm{C}, 55^{\circ} \mathrm{C}, 60^{\circ} \mathrm{C}, 65{ }^{\circ} \mathrm{C}$ dan variasi waktu reaksi 60 menit, 80 menit, 100 menit. Setelah suhu dan waktu reaksi terc apai, saring campuran larutan dari katalis heterogen kemudian dipisahkan campuran kedalam corong pemisah dan didiamkan selama 24 jam.Setelah didiamkan selama 24 jam akan terbentuk dua lapisan, lapisan atas metil ester dan lapisan bawah merupakan gliserol.

Proses pemurnian dilakukan dengan menggunakan washing. Metil ester pada lapisan atas dipisahakn dengan gliserol.Ditambahkan dengan aquadest yang telah dipanaskan didalam waterbath pada suhu $50{ }^{\circ} \mathrm{C}$ sampai $60{ }^{\circ} \mathrm{C}$, ke dalam corong pemisah sebanyak $50 \mathrm{ml}$. Larutan kemudian dikocok dan didiamkan hingga terbentuk dua lapisan. Metil ester yang terbentuk dibagian atas di dalam corong pemisah dipisahkan dengan zat pengotor dibagian bawahnya,perubahan volume dicatat. Pencucian dilakukan beberapa kali hingga bagian bawah di dalam 
corong pemisah berubah warna dari putih keruh menjadi bening dengan mendekati $\mathrm{pH}$ netral. Metil ester di saring dengan menggunakan corong. Metil ester hasil dari saringan disimpan di dalam botol sampel.

\section{Hasil dan Diskusi}

\subsection{Pengaruh Suhu dan Waktu Reaksi terhadap Yield (\%)}

Yield merupakan perbandingan berat produk terhadap berat bahan baku. Pada penelitian ini digunakan katalis dari abu tandan kosong kelapa sawit dengan variasi suhu $50{ }^{\circ} \mathrm{C}, 55^{\circ} \mathrm{C}, 60{ }^{\circ} \mathrm{C}, 65^{\circ} \mathrm{C}$, serta waktu reaksi 60 menit, 80 menit, dan 100 menit. Pengaruh suhu dan waktu reaksi terhadap yield biodiesel yang dihasilkan dapat dilihat dari Gambar 3.1:

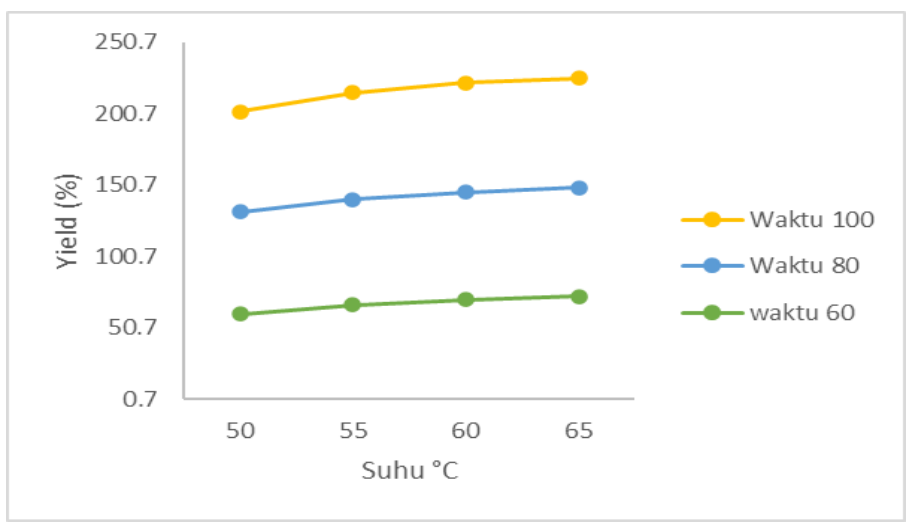

Gambar 3.1 Pengaruh Suhu dan Waktu Reaksi terhadap Yield (\%)

Berdasarkan teori, semakin tinggi suhu reaksi dan semakin lama waktu reaksi, maka kontak antar zat semakin besar sehingga akan menghasilkan konversi yang besar. Dalam penelitian yang telah dilakukan diperoleh data bahwa selama waktu 60 menit sampai dengan 100 menit pada suhu $50{ }^{\circ} \mathrm{C}$ sampai $65^{\circ} \mathrm{C}$, hasil konversi terus meningkat. Hal ini membuktikan bahwa semakin lama waktu reaksi dan semakin tinggi suhu yang diberikan maka akan semakin meningkatnya hasil. Gambar 3.1 dapat dilihat bahwa pada suhu reaksi $50{ }^{\circ} \mathrm{C}$ menghasilkan yield $60,4 \%$ dengan waktu reaksi 60 menit, kemudian pada suhu $55^{\circ} \mathrm{C}$ dengan waktu reaksi yang sama, yield yang dihasilkan meningkat menjadi 66,3\%. Pada suhu reaksi $60{ }^{\circ} \mathrm{C}$ yield yang diperoleh adalah 70,42\%,dan pada suhu $65{ }^{\circ} \mathrm{C}$ juga 
dengan waktu reaksi yang sama menghasilkan yield yang lebih tingi yaitu sebanyak $72.9 \%$.

Hal ini di karenakan adanya peningkatan suhu pada durasi waktu reaksi yang terjadi pada saat proses transesterifikasi pada produksi biodiesel menyebabkan semakin banyak molekul-molekul minyak yang bereaksi dengan metanol membentuk metil ester dan juga di pengaruhi oleh katalis yang digunakan. Katalis meningkatkan kelarutan metanol dan dengan demikian meningkatkan laju reaksi (Irawan, Arifin, Olivia, \& Nopal, 2019).

Pada gambar 3.1 bahwa suhu reaksi dan waktu reaksi optimum yaitu pada suhu $60{ }^{\circ} \mathrm{C}$ dan $65^{\circ} \mathrm{C}$ untuk reaksi transesterifikasi. Semakin meningkatnya suhu reaksi dan waktu reaksi maka akan semakin meningkatkan hasil yield yang didapatkan. Kondisi terbaik dari penelitian ini berdasarkan gambar 3.1 adalah dengan suhu $60{ }^{\circ} \mathrm{C}$ dan $65^{\circ} \mathrm{C}$ pada waktu 100 menit dengan yield tertinggi $76,8 \%$.

\subsection{Pengaruh Suhu dan Waktu Reaksi terhadap Densitas (gr/ml)}

Densitas atau berat jenis menunjukkan perbandingan berat persatuan volume. Densitas bertujuan untuk menentukan berat jenis suatu zat. Semakin rendah suhu, maka densitas biodiesel akan semakin tinggi dan begitu juga sebaliknya. Analisis densitas pada penelitian ini menggunakan piknometer. Pengaruh suhu dan waktu reaksi terhadap densitas dapat dilihat pada gambar 3.2 :

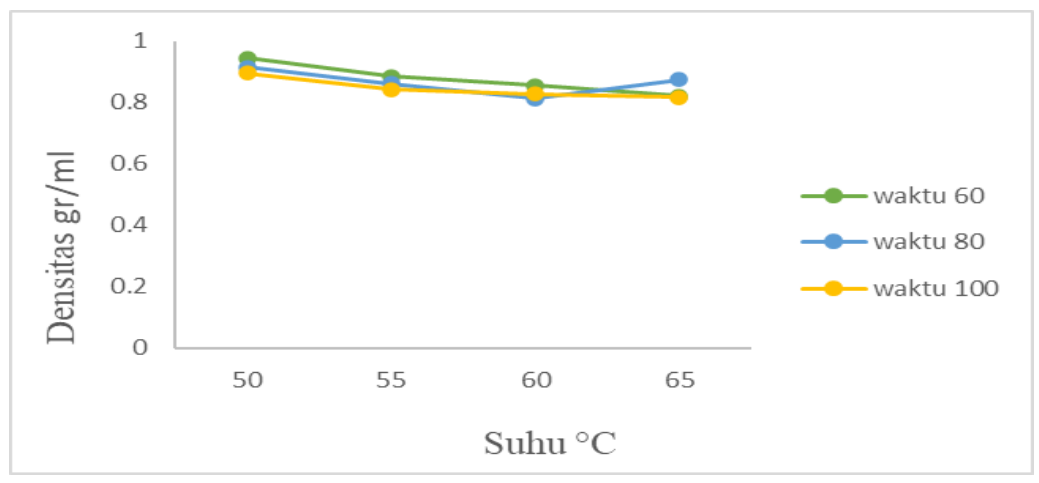

Gambar 3.2 Pengaruh Suhu dan Waktu Reaksi terhadap Densitas (gr/ml) 
Meningkatnya suhu dan waktu reaksi yang digunakan mempengaruhi densitas dari hasil biodiesel. Berdasarkan gambar grafik 3.2 dapat dilihat suhu dan waktu reaksi mempengaruhi densitas dari sampel biodiesel. pada suhu $50{ }^{\circ} \mathrm{C}$ pada waktu 60 menit densitas yang di peroleh adalah $0,945 \mathrm{gr} / \mathrm{ml}$, kemudian pada suhu $55{ }^{\circ} \mathrm{C}$ dengan kondisi waktu reaksi yang sama densitas yang di peroleh adalah $0,886 \mathrm{gr} / \mathrm{ml}$, pada suhu $60{ }^{\circ} \mathrm{C}$ dan $65^{\circ} \mathrm{C}$ densitas yang diperoleh mengalami penurunan yaitu $0,857 \mathrm{gr} / \mathrm{ml}$.dan $0,822 \mathrm{gr} / \mathrm{ml}$.

Berdasarkan hasil uji densitas yang di dapat, bahwa suhu dan waktu reaksi mempengaruhi densitas biodiesel, hasil yang didapatkan yaitu nilai densitas pada masing-masing sampel biodiesel dengan variasi suhu dan waktu reaksi mengalami peningkatan dan juga penurunan. Hal ini disebabkan karena densitas yang dihasilkan cukup tinggi dan juga dipengaruhi oleh kualitas biodiesel dan jumlah katalis yang digunakan. Pada penelitian ini kualitas metanol dan katalis yang digunakan sedikit, Dari hasil penelitian tidak semua nilai densitas sesuai dengan standar SNI yang mana dalam standar densitas SNI biodiesel yaitu pada range 0,85-0,89 $\mathrm{gr} / \mathrm{cm}^{3}$ Hal ini di karenakan kurang sempurnanya pada saat proses distilasi sehingga masih terdapat kandungan metanol dan juga kotoran di dalam sampel. Sehingga berdasarkan hasil yang di dapat, biodiesel dengan suhu $50{ }^{\circ} \mathrm{C}$ pada waktu reaksi 80 menit dan 100 menit yang memperoleh densitas sesuai dengan SNI.

\subsection{Pengaruh Suhu dan Waktu Reaksi terhadap Viskositas $\left(\mathrm{mm}^{2} / \mathrm{s}\right)$}

Salah satu parameter terpenting dalam pembuatan biodiesel adalah viskositas. Viskositas bahan bakar memberi pengaruh besar pada injector dan proses atomisasi bahan bakar. Jika viskositasnya terlalu kecil, bahan bakar tidak mampu menyediakan lubrikasi bagi pompa injeksi, namun jika viskositasnya terlalu tinggi akan menghasilkan tetesan-tetesan yang lebih besar sehingga dapat menyebabkan pembakaran yang tidak sempurna. Pengaruh suhu dan waktu reaksi terhadap viskositas dapat dilihat pada gambar 3.3 : 


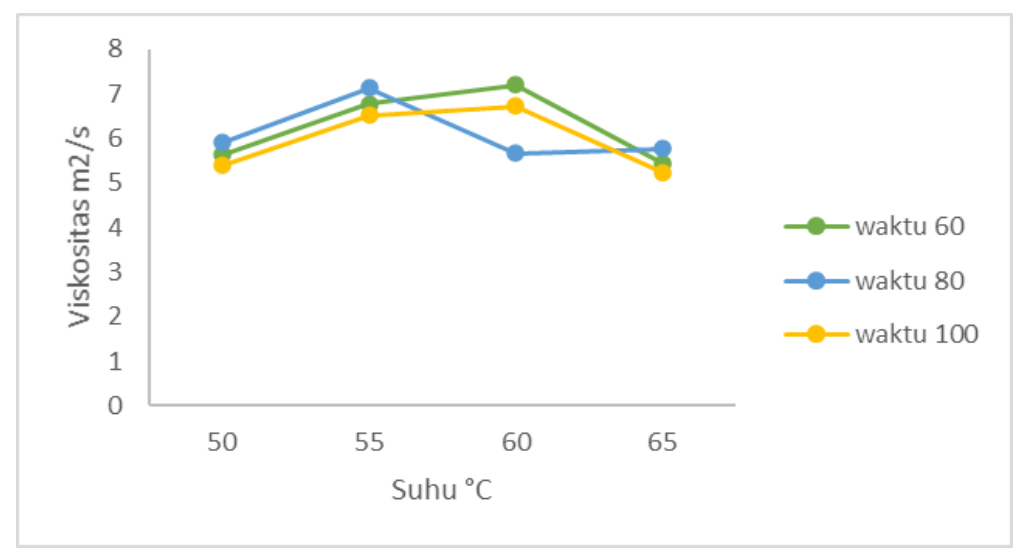

Gambar 3.3 Pengaruh Suhu dan Waktu Reaksi terhadap Viskositas $\left(\mathrm{m}^{2} / \mathrm{s}\right)$

Berdasarkan hasil yang diperoleh dapat dilihat dari gambar dengan variasi waktu 60 menit, 80 menit, dan 100 menit pada suhu $50{ }^{\circ} \mathrm{C}$, viskositas yang diperoleh yaitu 5,$64 ; 5,91$; dan $5,40 \mathrm{~mm}^{2} / \mathrm{s}$. untuk variasi waktu 60 menit, 80 menit, dan 100 menit pada suhu $55^{\circ} \mathrm{C}$, viskositas yang di peroleh yaitu 6,$78 ; 7,14$; dan $6,53 \mathrm{~mm}^{2} / \mathrm{s}$. Lalu untuk variasi waktu 60 menit, 80 menit, dan 100 menit pada suhu $60{ }^{\circ} \mathrm{C}$ di dapat nilai viskositas sebesar 7,21;5,67; dan $6,72 \mathrm{~mm}^{2} / \mathrm{s}$. Sedangkan untuk variasi waktu 60 menit, 80 menit, dan 100 menit pada suhu $65{ }^{\circ} \mathrm{C}$ di dapat nilai viskositas sebesar 5,44; 5,78; dan $5,25 \mathrm{~mm}^{2} / \mathrm{s}$.

Viskositas yang diharapkan adalah viskositas yang rendah sehingga akan memperkecil tahanan untuk mengalir.Viskositas kinematika yang terkecil terletak pada suhu $65{ }^{\circ} \mathrm{C}$ dengan waktu reaksi 60 menit adalah $5,25 \mathrm{~mm}^{2} / \mathrm{s}$. Dari hasil penelitian yang didapatkan dapat disimpulkan bahwa rata-rata viskositas dari setiap variabel sesuai dengan range SNI biodiesel yaitu 2,3-6,0 $\mathrm{mm}^{2} / \mathrm{s}$. Kemudian dapat dilihat nilai viskositas biodiesel, hasil yang didapatkan tidak konstan dan cendrung turun naik. Viskositas juga dipengaruhi oleh konversi biodiesel, semakin tinggi konversi biodiesel maka viskositas kinematik yang dihasilkan akan semakin rendah. Hal ini disebabkan semakin sedikit kadar asam lemak bebas yang masih berada pada biodiesel yang dihasilkan tersebut kemungkinan masih terdapat air dalam biodiesel akibat proses pencucian. 


\subsection{Pengaruh Suhu dan Waktu Reaksi terhadap Kadar Air (\%Vol)}

Kadar air adalah salah satu tolak ukur dari kualitas biodiesel. Kadar air yang tinggi dalam biodiesel akan menyebabkan turunnya panas pembakaran dan bersifat korosif jika bereaksi dengan sulfur. Kadar air yang tinggi pada minyak juga dapat menyebabkan proses hidrolisis sehingga menurunkan yield biodiesel yang dihasilkan. Pengaruh suhu dan waktu reaksi terhadap kadar air dapat dilihat pada gambar 3.4 :

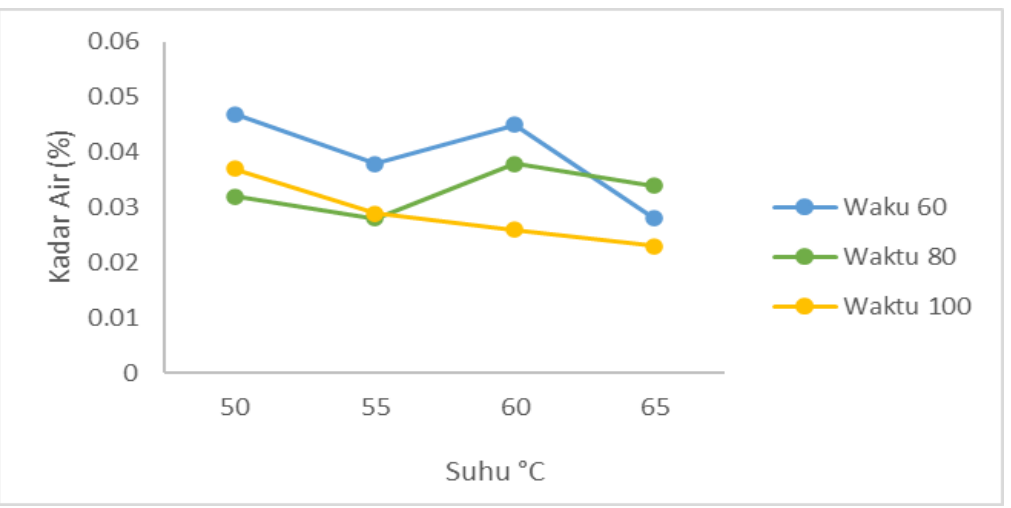

Gambar 3.4 Pengaruh Suhu dan Waktu Reaksi terhadap kadar air (\%vol)

Berdasarkan hasil yang diperoleh dapat dilihat dari gambar dengan variasi waktu 60 menit, 80 menit, dan 100 menit pada suhu $50^{\circ} \mathrm{C}$ didapat nialai kadar air yang diperoleh yaitu 0,$476 ; 0,034$; dan $0,027 \mathrm{~mm}^{2} / \mathrm{s}$. untuk variasi waktu 60 menit, 80 menit, dan 100 menit pada suhu $55^{\circ} \mathrm{C}$, viskositas yang di peroleh yaitu 0,032; 0,059; dan 0,028\%Vol. Lalu untuk variasi waktu 60 menit, 80 menit, dan 100 menit pada suhu $60{ }^{\circ} \mathrm{C}$ di dapat nilai viskositas sebesar 0,$024 ; 0,208$; dan 0,022\%Vol. Sedangkan untuk variasi waktu 60 menit, 80 menit, dan 100 menit pada suhu $65{ }^{\circ} \mathrm{C}$ di dapat nilai viskositas sebesar 0,058; 0,034; dan 0,038 \% Vol

Berdasarkan hasil uji kadar air yang didapat tersebut dapat kita lihat bahwa suhu dan waktu reaksi mempengaruhi kadar air biodiesel, hasil yang didapatkan yaitu kadar air pada masing-masing sampel biodiesel dengan variasi suhu dan waktu reaksi tidak konstan yaitu cendrung turun naik. Hal ini dipengaruhi oleh akumulasi air minyak jarak kepyar pada saat proses 
transesterifikasi. Kadar air tertinggi di peroleh pada suhu dan waktu reaksi dengan persentase $0,059 \% \mathrm{Vol}$

Kandungan air yang tinggi dalam biodiesel yang digunakan sebagaibahan bakar juga dapat menyebabkan turunnya panas pembakaran, berbusa, bersifat korosif jika bereaksi dengan sulfur karena akan membentuk asam, dan memberi ruang bagi mikroba untuk tumbuh sehingga akan menjadi pengotor bagi biodiesel (Adhani, Aziz, Nurbayti, \& Oktaviana, 2016).

Menurut Standar Nasional Indonesia (2015), batas maksimal kadar air pada biodiesel adalah $0,035 \% \mathrm{Vol}$, berdasarkan hasil peneltian kadar air yang di dapat sudah mendekati SNI 2015, namun ada sebagian yang belum memenuhi SNI 2015, hal ini bisa dikarenakan pada saat proses pemisahan antara metil ester dan gliserol yang kurang sempurna, sehingga masih ada sisa air yang terikut.

\subsection{Pengaruh Suhu dan Waktu Reaksi terhadap Bilangan Asam (Mg- $\mathrm{KOH} / \mathrm{g})$}

Angka asam adalah salah satu parameter yang dapat digunakan untuk mengukur kualitas suatu biodiesel. Semakin kecil angka asam maka akan semakin baik kualitas dari biodiesel. Semakin besar Ph terutama berkisar antara 6 hingga 7 , yaitu menuju netral makan semakin kecil angka asam serta semakin baik metil ester yang dihasilkan (M. Faizal, Ulfa Maftuchah, 2008). Pengaruh suhu dan reaksi terhadap bilangan asam dapat dilihat pada gambar 3.5 :

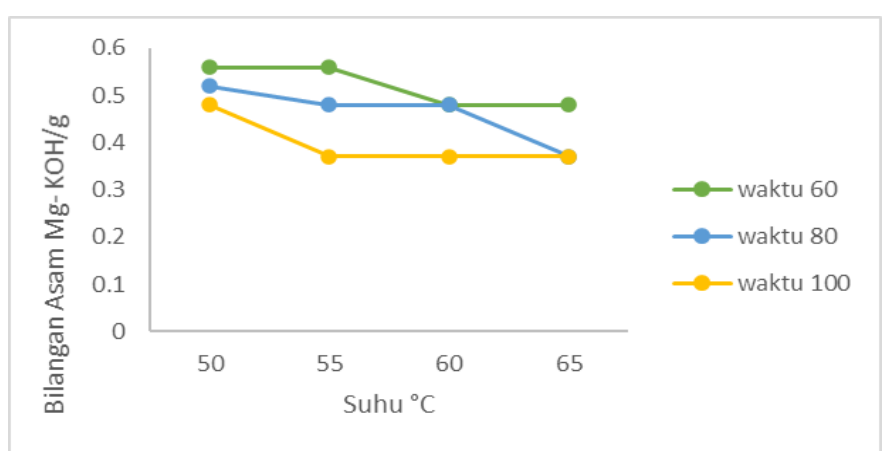

Gambar 3.5 Pengaruh Suhu dan Waktu Reaksi terhadap Bilangan Asam $(\mathrm{Mg}-\mathrm{KOH} / \mathrm{g})$ 
Berdasarkan hasil penelitian dapat dilihat pada gambar 4.5 semua sampel biodiesel masih memenuhi Standar Nasional Indonesia (SNI 2015) yang menyatakan bahwa batas maksimum bilangan asam yakni sebesar $0,5 \mathrm{Mg}-\mathrm{KOH} / \mathrm{g}$ dimana pada Berdasarkan hasil yang diperoleh dapat dilihat dari gambar dengan variasi waktu 60 menit, 80 menit, dan 100 menit pada suhu $50{ }^{\circ} \mathrm{C}$ didapat nilai bilangan asam yang diperoleh yaitu 0,56 ; 0,52; dan $0,48 \mathrm{Mg}-\mathrm{KOH} / \mathrm{g}$. untuk variasi waktu 60 menit, 80 menit, dan 100 menit pada suhu $55^{\circ} \mathrm{C}$, bilangan asam yang di peroleh yaitu 0,56 ; 0,56 ; dan $0,37 \mathrm{Mg}-\mathrm{KOH} / \mathrm{g}$. Lalu untuk variasi waktu 60 menit, 80 menit, dan 100 menit pada suhu $60^{\circ} \mathrm{C}$ di dapat nilai bilangan asam sebesar 0,48; 0,37; dan 0,37 Mg- KOH/g. Sedangkan untuk variasi waktu 60 menit, 80 menit, dan 100 menit pada suhu $65^{\circ} \mathrm{C}$ di dapat nilai bilangan asam sebesar 0,$56 ; 0,37$; dan $0,37 \mathrm{Mg}-\mathrm{KOH} / \mathrm{g}$.

Berdasarkan hasil uji bilangan asam yang didapat tersebut dapat dilihat bahwa pengaruh suhu dan waktu reaksi mempengaruhi bilangan asam biodiesel, hasil yang didapatkan yaitu kadar bilangan asam pada masing-masing sampel biodiesel dengan variasi suhu dan waktu tidak konstan cendrung turn-naik. Semakin lama waktu reaksi akan semakin memperkecil bilangan asam.

\subsection{Analisa Komposisi Senyawa Hidrokarbon dalam Biodiesel}

Gas Chromatography-Mass Spectrometry (GC-MS) Kromatografi gasspektrometri massa atau dikenal dengan GC-MS adalah metode kombinasi antara kromatografi gas dan spektrometri massa yang bertujuan untuk menganalisis berbagai senyawa dalam suatu sampel. Methyl ester hasil transesterifikasi minyak jarak kepyar menjadi biodiesel dengan variasi suhu dan waktu reaksi dianalisa menggunakan Gas Chromatography-Mass Spectroscopy (GC-MS). Analisis ini merupakan analisis kualitatif dan kuantitatif yang bisa digunakan untuk mengetahui jenis kandungan asam lemak dalam biodiesel beserta kuantitasnya. Methyl ester biodiesel yang telah di analisis dengan GC-MS menunjukkan lima puncak dominan seperti disajikan pada Gambar 4.6: 


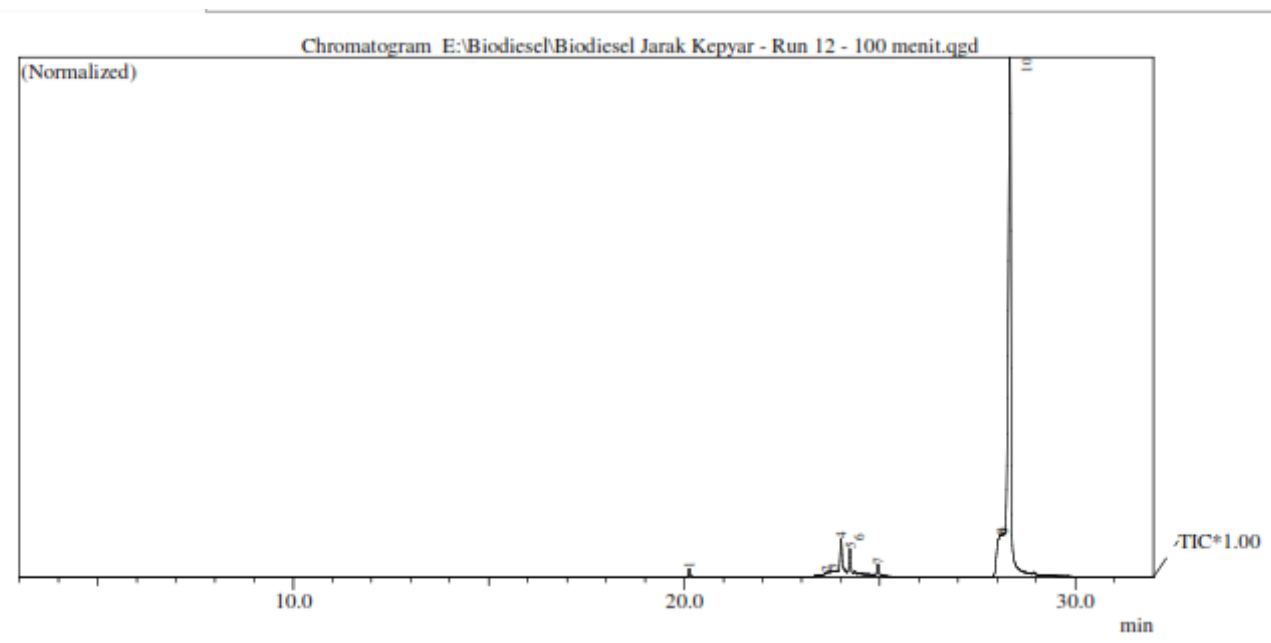

Peak Report TIC

\begin{tabular}{|c|r|r|r|l|}
\hline Peak\#\# & R.Time & Area & Area\% & Name \\
\hline 1 & 20.128 & 509692 & 0.71 & Hexadecanoic acid, methyl ester (CAS) Methyl palmitate SS Methyl hexadecanoate \\
\hline 2 & 23.642 & 613459 & 0.85 & 9-Octadecenoic acid (Z)-, methyl ester (CAS) Methyl oleate S\$ Oleic acid methyl ester \\
\hline 3 & 23.798 & 1060510 & 1.47 & 9-Octadecenoic acid (Z)-, methyl ester (CAS) Methyl oleate S\$ Oleic acid methyl ester \\
\hline 4 & 24.007 & 3487114 & 4.84 & $9,12-$ Octadecadienoic acid (Z,Z), methyl ester (CAS) Methyl linoleate \\
\hline 5 & 24.237 & 2202581 & 3.06 & $9-$ Octadecenoic acid (Z)-, methyl ester (CAS) Methyl oleate S\$ Oleic acid methyl ester \\
\hline 6 & 24.469 & 611627 & 0.85 & Cyclopentanetridecanoic acid, methyl ester \$\$ Methyl dihydrochaulmoograte \\
\hline 7 & 24.957 & 1073498 & 1.49 & Octadecanoic acid, methyl ester (CAS) Methyl stearate \$\$ Stearic acid methyl ester \\
\hline 8 & 28.093 & 6133364 & 8.52 & Methyl ricinoleate \\
\hline 9 & 28.156 & 3488063 & 4.85 & Methyl ricinoleate \\
\hline 10 & 28.330 & 52805821 & 73.36 & Methyl ricinoleate \\
\hline & & 71985729 & 100.00 & \\
\hline
\end{tabular}

Gambar 3.6 Hasil Analisa GC-MS

Gambar 3.6 merupakan kromatogram analisis komposisi metil ester menggunakan GC-MS. Dari kromatogram menunjukkan bahwa metil ester pada penelitian ini mengandung metil ester yang sesuai dengan asam-asam lemak yang terkandung dalam minyak jarak kepyar. Berdasarkan hasil analisis GC, komponen asam lemak yang utama pada sampel minyak jarak kepyar adalah pada puncak 8 sampai 10 yaitu asam ricinoleat sebesar $86,73 \%$, kemudian pada puncak 2 dan 3 yaitu asam lemak tidak jenuh berupa asam oleat sebesar 6,39\%, pada puncak 4 yaitu asam lemak tak jenuh berupa asam linoleat sebesar 4,84\%, pada puncak 7 yaitu asam lemak jenuh yaitu asam stearate sebesar 1,49\%, kemudian pada puncak 6 yaitu metyl dihydrochaulmoograte sebesar 0,85\%. Asam lemak terkecil dari hasil Analisa dengan GCMS adalah pada puncak 1 sebesar 0,71\%. Berdasarkan hasil Analisa uji GC-MS menunjukan bahwa data tersebut dapat dinyatakan memang benar senyawa biodiesel, yaitu metil ester. Ini menunjukan 
bahwa minyak jarak kepyar mampu menghasilkan biodiesel dalam bentuk metil esternya.

\subsection{Analisa SEM Morfologi dan Komposisi unsur pada \\ Katalis}

Untuk mengetahui morfologi permukaan katalis limbah maka dilakukan pengujian dengan menggunakan SEM-EDS (Scanning Electron Microscopy). Analisis dengan menggunakan SEM-EDS hanya menampilkan komponen dalam bentuk unsur yang dapat dilihat pada gambar 3.7

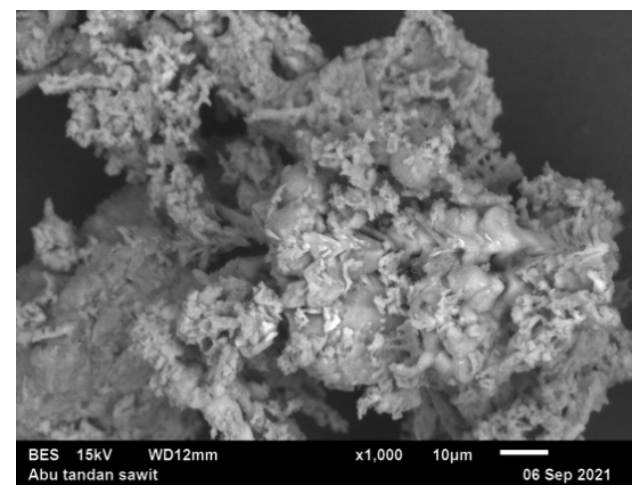

(a)

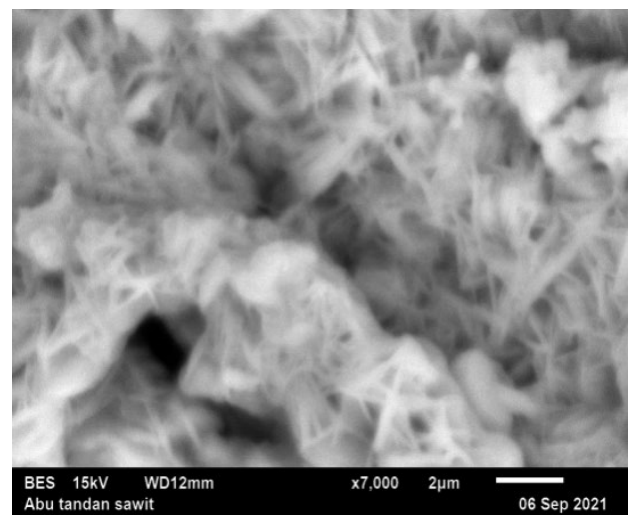

(c)

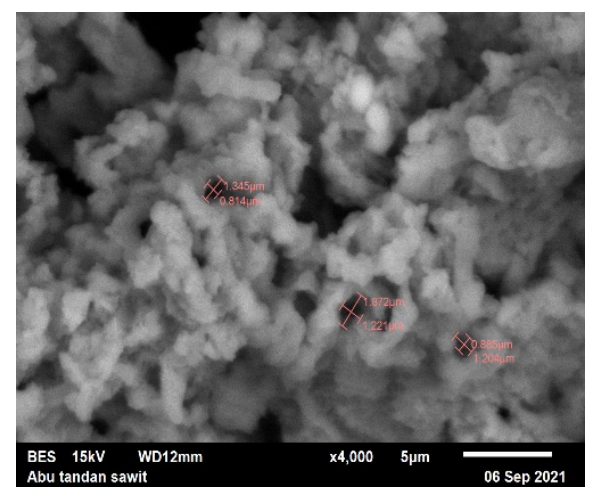

(b)

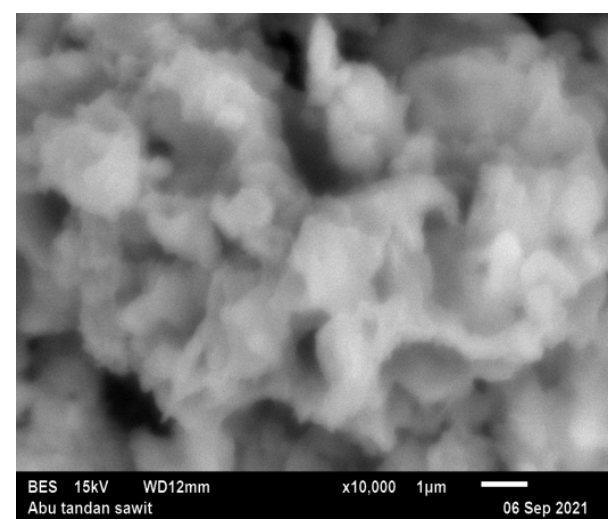

(d)

Gambar 4.7 Foto hasil uji SEM abu tandan kosong kelapa sawit dengan pembesaran (a) 1000x (b) 4000x (c) 7000x (d) 10.000x

Tujuan Analisa SEM abu tandan kosong kelapa sawit adalah untuk mengetahui struktur morfologi dari abu tandan kosong kelapa sawit. Dari gambar hasil Analisa SEM di atas menunjukkan struktur morfologi abu tandan kosong 
kelapa sawit dari hasil uji Analisa SEM. Pada gambar (a) terlihat dengan jelas struktur dari abu tandan kosong kelapa sawit, dengan perbesaran 1000x serta ukuran partikel nya $10 \mu \mathrm{m}$, permukaan yang berwarna hitam dari struktur abu tandan kosong kelapa sawit merupakan karbon. Sisi berwarna hitam mengindikasikan keberadaan pori karbon. dan juga menunjukkan bahwa partikel yang menutupi permukaan karbon setelah sampel morfologi seperti lempengan yang menyatu antara satu sama lain dan sedikit berlubang. Pada gambar (b) tmenunjukkan hasil analisa uji SEM dari abu tandan kosong kelapa sawit dengan perbesaran 4000x, abu tandan kosong kelapa sawit menunjukkan ukuran permukaan kasar dengan diameter $1,345 \mu \mathrm{m}$ dan $0.8141 \mu \mathrm{m}$,kemudian permukaan kedua menunjukkan ukuran dimameter $1,87210 \mu \mathrm{m}$ dan dan $1,221 \mu \mathrm{m}$,permukaan ketiga menunjukkan ukuran diameter $0,885 \mu \mathrm{m}$ dan $1,204 \mu \mathrm{m}$, dari hasil perbesaran 4000x terlihat ukuran permukaan partikel dengan ukuran yang berbeda beda.ukuran partikel terbesar yaitu pada ukuran kedua sebesar $1,87210 \mu \mathrm{m}$ dan dan $1,221 \mu \mathrm{m}$. Pada gambar (c) menunjukkan hasil Analisa uji SEM dari abu tandan kosong kelapa sawit dengan perbesaran 7000x, abu tandan kosong kelapa sawit menunjukkan serat dari abu tandan kosong kelapa sawit dengan ukuran diameter $2 \mu \mathrm{m}$ dengan permukaan yang kasar, morfologi yang kasar ini disebabkan oleh kandungan lapisan lilin,substansi lemak dan pengotor.morfologi serat tersebut menunjukkan adanya pori, zat yang termasuk minyak dan pengotor lain yang menutup permukaan serat. Pada gambar (d) menunjukkan hasil analisa uji SEM dari abu tandan kosong kelapa sawit dengan perbesaran 10000x, abu tandan kosong kelapa sawit ukuran diameter $1 \mu \mathrm{m}$ dengan permukaan pori seperti lempengan yang sedikit berlubang yang menyatu satu sama lain,strukturnya tidak beraturan,sudah terlihat struktur morfologi abu tandan kosong kelapa sawit.

\section{Simpulan dan Saran}

Limbah tandan kosong kelapa sawit dapat digunakan sebagai katalis heterogen dalam pembuatan biodiesel dari minyak jarak kepyar dengan hasil yield tertinggi yaitu $76,62 \%$ pada suhu $65^{\circ} \mathrm{C}$ dan waktu reaksi 100 menit. Hasil GC-MS 
membuktikan bahwa hasil yang diperoleh adalah methyl ester, dimana diperoleh komposisi minyak kepyar di antara nya asam ricinoleat sebesar $86,73 \%$, asam oleat sebesar 6,39\%, asam linoleat sebesar 4,84\%, asam stearat 1,49\%, methyl dihydrochaulmoograte sebesar $0,85 \%$. Analisis sifat fisika pada biodiesel dengan kondisi terbaik meliputi analisis kadar ester diperoleh sebesar 76,62\%, densitas yang diperoleh $0,863 \mathrm{gr} / \mathrm{ml}$, viskositas yang diperoleh $5,25 \mathrm{~mm}^{2} / \mathrm{s}$, kadar air yang diperoleh 0,038\%vol, dan bilangan asam yang diperoleh 0,48 Mg-KOH/g. hasil tersebut sudah hampir mendekati Standar Nasional Indonesia (SNI 7182: 2015)

Adapun saran yang dapat diberikan dari hasil penelitian ini adalah diharapkan untuk penelitian selanjutnya dapat dilakukan variasi perbandingan mol reaktan untuk melihat perbandingan molar reaktannya serta perlu dilakukan penelitian lebih lanjut dengan penggunaan bahan baku lain seperti : minyak kepayang, minyak malapari, serta ditambahkan dengan pengujian biodiesel lainnya seperti angka setana, angka iodium, titik nyala dan titik kabut.

\section{Daftar Pustaka}

1. Adhani, L., Aziz, I., Nurbayti, S., \& Oktaviana, C. O. (2016). Pembuatan Biodiesel dengan Cara Adsorpsi dan Transesterifikasi Dari Minyak Goreng Bekas. 2(15), 71-80.

2. Alif Aldino Rizkita, Anisa Helena.I.P, Anita Puspitasari Fina Rifqiyani, M. Faishal, M. I. A. (2016). Pengaruh suhu dan waktu proses terhadap mutu biodiesel dari minyak nabati dengan katalis basa. x(x), 1-7.

3. Erlinda Ningsih, S. (2017). Karakteristik biodiesel dengan menggunakan etanol konsentrasi rendah. 3(1).

4. Irawan, D., Arifin, Z., Olivia, C., \& Nopal, M. (2019). Pengaruh Rasio Metanol Dan Koh Pada Proses Pembuatan Biodiesel Dengan Metode Elektrolisis Menggunakan Elektroda Perak. 268-272.

5. Karim Abdullah, Z. dan M. D. J. (2016). Pengaruh penambahan tandan kosong kelapa sawit terhadap kualitas briket berbahan utama limbah kulit singkong. 49-58.

6. M. Faizal, Ulfa Maftuchah, W. A. A. (2008). Lemak Sapi Melalui Proses Transesterifikasi. (x), 29-37.

7. Saripah sobah, Muhammad Naufal Ariq H, siahaan T. (2021). Pembuatan 
Lidya Permata Sari / Chemical Engineering Journal Storage 1 :2 (Oktober 2021) 64-80

Biodisel dari Minyak Jarak dengan Metode TransesterifikasI Menggunakan Etanol Teknis dan Metanol PA. 1(1), 30-37.

8. Sinaga, S. V., Haryanto, A., \& Triyono, S. (2014). Pengaruh Suhu Dan Waktu Reaksi Pada Pembuatan Biodiesel Dari Minyak Jelantah [ Effects Of Temperature And Reaction Time On The Biodiesel Production Using Waste Cooking Oil ]. 3(1), 27-34.

9. Tazora. (2011). Peningkatan Mutu Biodiesel Dari Minyak Jarak Kepyar (Ricinus Communis) Melalui Pencampuran Biodiesel Dari Minyak Nyampung (Calophyllum inophyllum. 100, 1-8. 